\title{
PEMANFAATAN MEDIA PEMBELAJARAN BERBASIS VIDEO SEBAGAI ALTERNATIF DALAM PEMBELAJARAN DARING IPA DI MTs. NEGERI 1 OKU TIMUR
}

\author{
HANANI \\ MTs. Negeri 1 OKU Timur Sumatera Selatan \\ Email : nanihanani388@gmail.com
}

\begin{abstract}
ABSTRAK
Pembelajaran daring disarankan menggunakan media pembelajaran yang inovatif dan kreatif khususnya pada mata pelajaran IPAuntuk meningkatkan motivasi peserta didik ketika sedang belajar di rumah. Pemanfaatan media pembelajaran yang berbasis video dalam pembelajaran daring pada mata pelajaran IPA merupakan suatu pemanfaatan teknologi pembelajaran sesuai perkembangan zaman dengan upaya untuk meningkatkkan mutu pendidikan. Best practice disusun dengan tujuan untuk mengetahui manfaat media pembelajaran yang berbasis video sebagai alterntif dalam pembelajaran daring pada mata pelajaran IPA kelas VIII MTs.Negeri 1 OKU Timur . Praktek terbaik dilaksanakan pada semester ganjil tahun pelajaran 2020/2021 yaitu mulai bulan Juli sampai dengan Nopember. Karya Tulis Ilmiah ini menggambarkan tentang peningkatan minat dan motivasi dengan memanfaatkan media pembelajaran yang berbasis video sebagai alternatif pada pembelajaran daring IPA. dan peningkatan nilai rata-rata peserta didik. Adapun subyek penelitian yaitu peserta didik kelas VIII.1 sampai dengan VIII.7, dengan membawa perubahan yang signifikan, yaitu sebelum menggunakan video hanya $21,4 \%$ atau 48 siswa dengan memanfaatkan media yang berbasis video minat dan motivasi peserta didik meningkat menjadi 79,5\% atau 178 siswa, mengalami peningkatan sebesar 58,1\%. Berdasarkan minat dan motivasi belajar ternyata terdapat perubahan didalam nilai rata-rata peserta didik yaitu pada Bab I hanya dengan nilai rata-rata 52 dan terus mengalami peningkatan hingga bab VI mencapai angka 82.
\end{abstract}

Kata Kunci: Pembelajaran Daring, Pembelajaran berbasis video, minat dan motivasi

\section{PENDAHULUAN}

Pembelajaran harus tetap berlangsung, walaupun terjadi bencana pandemi global yang menjadikan pemerintah menerapkan social distancing pada dunia pendidikan. Solusi paling tepat dengan pandemi ini adalah pembelajaran daring. Pelaksanakan pembelajaran daring adalah salah satu model pembelajaran yang dilakukan pada masa pandemi, karena dalam prinsip kebijakan pendidikan di masa pandemi ini adalah mengutamakan kesehatan dan keselamatan para peserta didik, para pendidik, tenaga kependidikan, keluarga, dan masyarakat pada umumnya. Pembelajaran daring pada dasarnya merupakan pembelajaran yang dilakukan secara virtual melalui aplikasi virtual yang tersedia. Walaupun demikian, pembelajaran daring harus tetap memperhatikan kompetensi yang akan diajarkan.

Penerapan pembelajaran daring ini tentu menuntut kesiapan berbagai pihak, baik dari pihak sekolah, pemangku jabatan, dan pihak peserta didik itu sendiri. Pembelajaran daring dapat dilaksanakan dengan menggunakan model interaktif berbasis internet dan Learning Manajemen System (LSM). Misalnya dengan menggunakan aplikasi video, WhatsApp, Google, Zoom, dan lain-lain. Pembelajaran daring tentu memberikan dampak bagi kita yang menjalankannya. Salah satu dampak positifnya adalah guru dan siswa menjadi lebih mampu dalam menggunakan aplikasi pembelajaran, pelaksanaan pembelajaran menjadi lebih fleksibel sebab bisa dilaksanakan di rumah dan bisa dilaksanakan di mana saja. Selain itu pembelajaran ini tentu juga memiliki dampak negatif bagi yang menjalankannya. Seperti terjadinya kesalahpahaman, karena komunikasi dilakukan tanpa tatap muka, jaringan internet sering tidak lancar terutama daerah pelosok yang susah jangkauan, dan memerlukan teknologi yang baik. 
Pemilihan jenis aplikasi untuk pembelajaran daring disesuaikan dengan berbagai kondisi. Hal ini berdasarkan pertimbangan berbagai kendala yang dihadapi. Kendala yang ditemui antara lain jaringan internet yang lemah dan tidak stabil (U.hasanah et al., 2020). Menurut Obiakor \& Adeniran ( Ahmad Muzawir Saleh, 2020) bahwa kendala lain yang ditemukan yakni kemampuan orang tua untuk memberikan fasilitas pendidikan online , baik failitas berupa alat komunikasi (HP/Laptop) maupun biaya penggunaan jaringan internet .

Berdasarkan permasalahan tersebut diatas, maka diperlukan sebuah solusi ataualternatif untuk menjawab permasalahan tersebut. Solusinya guru dituntut dapat mendesain pembelajaran sebagai inovasi dengan memanfaatkan media pembelajaran daring (online). Menggunakan media pembelajaran daring yang inovatif khususnya pada mata pelajaran IPA untuk meningkatkan motivasi peserta didik ketika sedang belajar di rumah. Namun Beberapa siswa yang tidak memliki gadget, handphone ataupun komputer melakukan pembelajaran secara berkelompok, sehingga mereka melakukan aktifitas pembelajaran pun bersama. Mulai belajar melalui video call yang dihubungkan dengan guru yangbersangkutan, diberi pertanyaan satupersatu hingga mengabsen melalui voice note yang tersedia melalui media aplikasi WhatsApp Group dan aplikasi telegram group. Materi-materinya pun diberikan dalam bentuk Video pembelajaran maupun video tutorial yang berdurasi 5-10 menit. Namun beberapa guru di sekolah mengaku, jika pembelajaran daring ini tidak seefektif kegiatan belajar secara konvensional (tatap muka langsung), dikarenakan ada beberapa materi yang harus dijelaskan secara langsung dan lebih lengkap. Selain itu, materi yang disampaikan secara daring belum tentu bisa dipahami oleh semua siswa. Berdasarkan pengalaman mengajar beberapa guru secara daring, sistem ini hanya efektif untuk memberikan sebuah penugasan dan kemungkinan hasil dari pengerjaantugas-tugasnya itu diberikan ketika siswa akan masuk. Sehingga kemungkinan tugas-tugas akan semakin menumpuk.

Mengamati pengalaman beberapa guru tersebut, maka guru harus siap menggunakan teknologi sesuai perkembangan zaman. Guru harus mampu membuat model dan media pembelajaran daring yang sesuai dengan karakter siswa di sekolahnya juga kesesuaian terhadap materi-materi yang diajarkan khususnya dalam mata pelajaran IPA. Penggunaan beberapa aplikasi pada pembelajaran daring sangat membantu guru dalam melaksanakan proses pembelajaran ini. Guru dituntut harus terbiasa mengajar dengan menggunakan dan memanfaatkan media pembelajarandaring yang kompleks yang harus dikemas dengan efektif, mudah diakses dan dipahami oleh seluruh siswanya, salah satunya dengan memanfaatkan aplikasi yang berbasis video agar siswa memiliki motivasi untuk belajar.

Beberapa penelitian terdahulu yang pernah dilakukan (oleh Rimba et al. 2017) menunjukan bahwa video efektif digunakan dalam penyuluhan karena rata-rata skor sebelum menggunakan video nilai 61,33 meningkat menjadi 89,10 setelah menggunakan video dan peningkatan hasil belajar tersebut berada signifikan. Hasil penelitian Michels \& Kristin (2016), integrasi video menggunakan mikroskop membantu pengembangan keterampilan berpikir teknis dan tata ruang yang penting untuk meningkatkan peserta didik berpikir kritis dan keterampilan pemecahan masalah. Sebagian peserta didik (79\%) menanggapi bahwa video dari pengamatan mikroskop ditampilkan di laboratorium sangat membantu pemahaman mereka tentang biologi selular. Respon peserta didik bervariasi dalam upaya memanfaatkan video dari pengamatan di mikroskop $43 \%$ dari peserta didik jarang menggunakan aplikasi video, sedangkan $61 \%$ dari peserta didik sering menggunakan video online.

Penelitian yang pernah di lakukan (oleh Iqbal M, et all, 2019) meneliti tentang pengembangan video blog (vlog) channel Youtube dengan pendekatan system sebagaimedia alternatif pembelajaran daring. Penelitian ini bertujuan untuk mengembangkan video blog (vlog) berbantuan kanal Youtube sebagai alternative pembelajaran Fisika dengan pendekatan STEM. Berdasarkan hasil penelitiannyadiperoleh persentase hasil penilaian ahli media $84 \%$, ahli matei $84 \%$ dan penilaian ahli IT $72 \%$. Respon siswa pada uji coba kelompok kecil memperoleh persentase $87 \%$ dan uji coba lapangan $83 \%$. Berdasarkan hasil tersebut, dapat 
disimpulkan bahwa video vlog channel Youtube dengan pendekatan STEM layak digunakan sebagai media alternative pembelajaran daring peserta didik sekolah SMA/MA.

Penelitian yang dilakukan (oleh Hamdan Husen Batubara, et all 2020) dengan judul penelitian penggunaan video tutorial untuk mendukung pembelajaran daring di masa pandemi covid 19. Berdasarkan hasil penelitiannya menyatakan bahwa proses penggunaan video tutorial sebagai media pembelajaran yang terdiri dari empat tahap yaitu persiapan, perekaman, penyelesaian akhir implementasi. Respon mahasiswa terhadap penggunaan video tutorial memperoleh skor 4,09 yang berarti baik.

Berdasarkan beberapa penelitian terdahulu, pada dasarnya penggunaan video merupakan suatu pemanfaatan hasil teknologi pembelajaran sesuai perkembangan zaman dengan upaya meningkatkan mutu pendidikan. Penggunaan media berfungsi untuk membuat pembelajaran lebih efektif dalam berbagai situasi. Terutama di zaman modern dengan penggunaan akses teknologi yang bisa digunakan kapanpun dan dimanapun sehingga video dapat dijadikan sebagai media yang efisien dalam penggunaan media pembelajaran daring.

MTs Negeri 1 OKU Timur adalah sebuah madrasah yang terletak di kota Martapura Kabupaten OKU Timur Sumatera Selatan yang memiliki siswa sebanyak 983 siswa, madrasah ini sedang berupaya memanfaatkantekonologi informasi dalam kegiatan belajar mengajar. Siswa yang bersekolah di sini berasal dari 4 kecamatan yang ada wilayah Kabupaten OKU Timur dengan latar belakang yag berbeda dan mereka juga sebagian besar sudah "melek" teknologi dalam keseharian mereka. Sehingga dalam pembelajaran daring telah menggunakan media pembelajaran dari berbagai aplikasi seperti Google Classroom, Zoom, Google Meet, Whatsapp Group dan lain sebagainya. Namun sebagian siswa merasa jenuh dan bosan setiap menerima materi yang diberikan oleh guru, sehingga guru MTs.N 1 OKU Timur dituntut untuk lebih variatif dan inovatif dalam memberikan materi kepada siswa. Berdasarkan hal tersebut sehingga penulis melakukan best practice dengan harapan membawa perubahan pada peningkatan prestasi peserta didik.

Pembelajaran daring IPA dengan memanfaatkan media pembelajaran yang berbasis video telah saya praktekkan di kelas VIII tahun pelajaran 2020/2021. Berdasarkan hasil penelitian di kelas VIII.1 s/d VIII.7 sebelum menggunakan video minat dan motivasi belajar hanya 21,4 \% atau 48 siswa dengan memanfaatkan media yang berbasis video minat dan motivasi peserta didik meningkat menjadi $79,5 \%$ atau 178 siswa. Dengan peningkatan minat dan motivasi siswa dalam pembelajaran daring dengan media video tersebut, setidaknya telah mewakili guru dalam memberikan pengajaran yang sesuai dengan kebutuhan siswa di masa Pandemi Covid-19.

\section{METODE PELAKSANAAN}

Pemanfaatan video pembelajaran sebagai alternatif dalam pembelajaran daring IPA dipilih oleh penulis sebagai praktek terbaik pada masa pandemi covid -19. Best practice dilaksanakan karena mampu memberikan perubahan bagi peserta didik dengan metode yang bersifat ekonomis dan efesien. Data yang digunakan dalam best practice ini adalah data-data dari jejak pelaksanaan kegiatan yang telah dilalui berupa hasil dokumentasi, keaktifan , absen, minat, respon, video pembelajaran, daftar nilai, dan lain-lain. Best practice digambarkan dalam bentuk tabel dan grafik.

Adapun best practice dilaksanakan di kelas VIII.1 - VIII.7 berjumlah 224 siswa pada semester ganjil tahun pelajaran 2020/2021 yaitu mulai tgl 17 Juli sampai dengan 09 November 2020. Tempat pelaksanaan best practice adalah MTs. Negeri 1 OKU Timur, Jalan Merdeka Cidawang Martapura Kelurahan Paku Sengkunyit Kecamatan Martapura Kabupaten OKU Timur Porpinsi Sumatera Selatan. Bahan yang digunakan untuk best practice adalah video pembelajaran yang berkaitan dengan materi pelajaran IPA kelas VIII semester ganjil. 


\section{HASIL DAN PEMBAHASAN}

\section{Hasil}

Respon Peserta Didik terhadap pemanfaatan media pembelajaran yang berbasis video sebagai alternatif dalam pembelajaran Daring IPA bisa dilihat dari gambar grafik 1 di bawah ini yang menggambarkan seberapa minat dan motivasi peserta didik dalam pemanfaatan media video dalam menerima materi pelajaran. Grafik batang yang berwarna biru menunjukkan jumlah peserta didik yang berminat dan yang berwarna merah menunjukkan jumlah peserta yang tidak minat dalam setiap Bab, mulai Bab I sampai dengan Bab VI. Grafik tersebut menunjukkan adanya peningkatan minat peserta didik pada setiap pembelajaran mulai dari Bab I sampai dengan Bab VI.

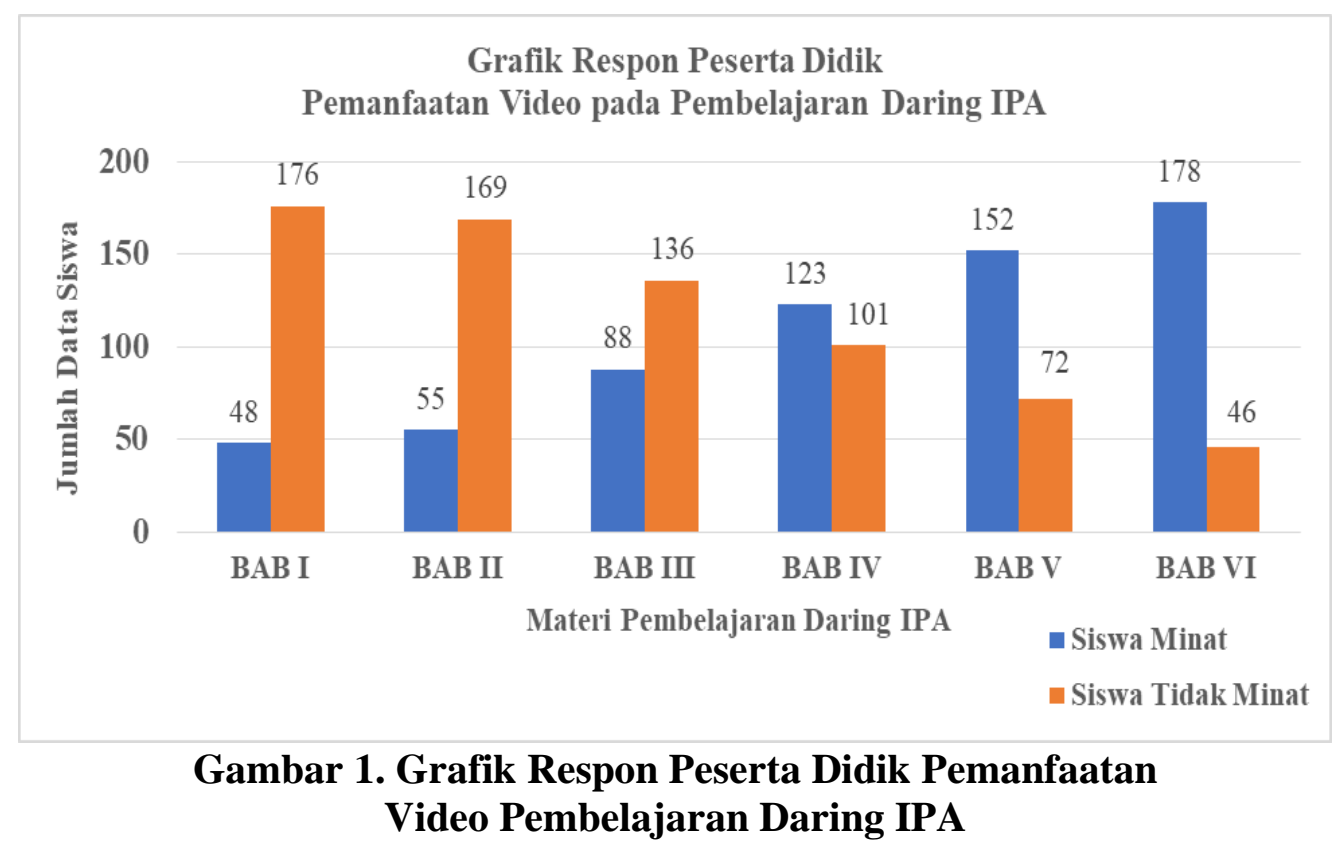

Tabel 1 berikut menunjukkan tentang daftar variabel kegiatan yang digunakan dalam kegiatan pembelajaran daring IPA dengan memanfaatkan media pembelajaran berbasis video.

Tabel 2. Daftar variabel dalam pelaksanaan pembelajaran daring dengan menggunakan

\begin{tabular}{|c|c|c|c|c|c|}
\hline \multicolumn{6}{|c|}{ video } \\
\hline $\mathrm{BAB}$ & $\begin{array}{c}\text { Hari / } \\
\text { tanggal }\end{array}$ & Materi & $\begin{array}{c}\text { Media } \\
\text { pembelajaran }\end{array}$ & $\begin{array}{c}\text { Bentuk } \\
\text { Tugas }\end{array}$ & $\begin{array}{l}\text { Bentuk } \\
\text { Respon }\end{array}$ \\
\hline \multirow{3}{*}{$\begin{array}{l}\text { BAB I } \\
\text { Gerak } \\
\text { benda } \\
\text { dan } \\
\text { Makhluk } \\
\text { hidup d } \\
\text { lingkung } \\
\text { an } \\
\text { sekitar }\end{array}$} & $\begin{array}{l}\text { Jum'at, } 17 \\
\text { Juli } 2020\end{array}$ & $\begin{array}{l}\text { Sistem } \\
\text { Gerak } \\
\text { Pada } \\
\text { Manusia }\end{array}$ & WA GROUP & $\begin{array}{l}\text { Ada } \\
\text { (foto selfi, } \\
\text { meringkas } \\
\text { menggambar) }\end{array}$ & $\begin{array}{l}\text { Ada } \\
\text { (foto selfi, } \\
\text { mengumpulka } \\
\text { n tugas, } \\
\text { bertanya ) }\end{array}$ \\
\hline & $\begin{array}{l}\text { Senin , } 20 \\
\text { Juli } 2020\end{array}$ & $\begin{array}{l}\text { Gerak } \\
\text { Pada } \\
\text { Hewan } \\
\text { dan } \\
\text { tumbuhan }\end{array}$ & WA GROUP & $\begin{array}{l}\text { Ada } \\
\text { (foto selfi, } \\
\text { meringkas } \\
\text { menggambar) }\end{array}$ & $\begin{array}{l}\text { Ada } \\
\text { (foto selfi, } \\
\text { mengumpulka } \\
\text { n tugas, } \\
\text { bertanya ) }\end{array}$ \\
\hline & $\begin{array}{l}\text { Jum'at, } 24 \\
\text { Juli } 2020\end{array}$ & $\begin{array}{l}\text { Gerak } \\
\text { pada } \\
\text { benda }\end{array}$ & WA GROUP & $\begin{array}{l}\text { Ada } \\
\text { (foto selfi, } \\
\text { menjawab } \\
\text { soal) }\end{array}$ & $\begin{array}{l}\text { Ada } \\
\text { (foto selfi, } \\
\text { mengumpulka } \\
\text { n tugas, } \\
\text { bertanya ) }\end{array}$ \\
\hline
\end{tabular}


Vol. 1 No. 2 Agustus 2021, e-ISSN : 2797-0140 | p-ISSN : 2797-0590

\begin{tabular}{|c|c|c|c|c|c|}
\hline & $\begin{array}{l}\text { Senin , } 27 \\
\text { Juli } 2020\end{array}$ & $\begin{array}{l}\text { Gaya dan } \\
\text { Hukum } \\
\text { Newton }\end{array}$ & WA GROUP & $\begin{array}{l}\text { Ada } \\
\text { (foto selfi, } \\
\text { menjawab } \\
\text { soal) }\end{array}$ & $\begin{array}{l}\text { Ada } \\
\text { (foto selfi, } \\
\text { mengumpulka } \\
\text { n tugas, } \\
\text { bertanya ) }\end{array}$ \\
\hline \multirow{2}{*}{$\begin{array}{l}\text { BAB II } \\
\text { Pesawat } \\
\text { Sederhan } \\
\text { a dalam } \\
\text { kehidupa } \\
\text { n sehari- } \\
\text { hari }\end{array}$} & $\begin{array}{l}\text { Jum'at, } 14 \\
\text { Agustus } \\
2020\end{array}$ & Usaha & WA GROUP & $\begin{array}{l}\text { Ada } \\
\text { (foto selfi, } \\
\text { Membuat } \\
\text { laporan) }\end{array}$ & $\begin{array}{l}\text { Ada } \\
\text { (foto selfi, } \\
\text { mengumpulka } \\
\text { n laporan ) }\end{array}$ \\
\hline & $\begin{array}{l}\text { Senin , } 24 \\
\text { Agustus } \\
2020\end{array}$ & $\begin{array}{l}\text { Pesawat } \\
\text { Sederhana }\end{array}$ & WA GROUP & $\begin{array}{l}\text { Ada } \\
\text { (foto selfi, } \\
\text { menjawab } \\
\text { soal) }\end{array}$ & $\begin{array}{l}\text { Ada } \\
\text { (foto selfi, } \\
\text { mengumpulka } \\
\text { n tugas ) }\end{array}$ \\
\hline \multirow{2}{*}{$\begin{array}{l}\text { BAB III } \\
\text { Struktur } \\
\text { dan } \\
\text { Fungsi } \\
\text { Jaringan } \\
\text { Tumbuh } \\
\text { an }\end{array}$} & $\begin{array}{l}\text { Senin , 07 } \\
\text { September } \\
2020\end{array}$ & $\begin{array}{l}\text { Struktur } \\
\text { dan } \\
\text { Fungsi } \\
\text { akar, } \\
\text { batang, } \\
\text { daun dan } \\
\text { bunga. }\end{array}$ & $\begin{array}{l}\text { Video } \\
\text { youtobe } \\
\text { Praktikum, } \\
\text { channel } \\
\text { Mutmaina } \\
\text { Jufri }\end{array}$ & $\begin{array}{l}\text { Ada } \\
\text { (foto selfi, } \\
\text { membuat } \\
\text { laporan, } \\
\text { meringkas) }\end{array}$ & $\begin{array}{l}\text { Ada } \\
\text { (foto selfi, } \\
\text { mengumpulka } \\
\text { n laporan dan } \\
\text { tugas ) }\end{array}$ \\
\hline & $\begin{array}{l}\text { Jum'at, } 11 \\
\text { September } \\
2020\end{array}$ & $\begin{array}{l}\text { Struktur } \\
\text { da fungsi } \\
\text { tumbuhan }\end{array}$ & $\begin{array}{l}\text { Video } \\
\text { youtobe } \\
\text { channel } \\
\text { Sigma Smart } \\
\text { Study }\end{array}$ & $\begin{array}{l}\text { Ada } \\
\text { (foto selfi, } \\
\text { membuat } \\
\text { laporan, } \\
\text { meringkas) }\end{array}$ & $\begin{array}{l}\text { Ada } \\
\text { (foto selfi, } \\
\text { mengumpulka } \\
\text { n laporan dan } \\
\text { tugas ) }\end{array}$ \\
\hline \multirow[t]{2}{*}{$\begin{array}{l}\text { BAB IV } \\
\text { Sistem } \\
\text { Pencerna } \\
\text { an } \\
\text { Manusia }\end{array}$} & $\begin{array}{l}\text { Senin, } 28 \\
\text { September } \\
2020\end{array}$ & $\begin{array}{l}\text { Zat } \\
\text { makanan }\end{array}$ & $\begin{array}{l}\text { Video } \\
\text { Youtobe } \\
\text { praktikumcha } \\
\text { nnel Zenius } \\
\text { dan channel } \\
\text { ibu Hanani }\end{array}$ & $\begin{array}{l}\text { Ada } \\
\text { (foto selfi, } \\
\text { membuat } \\
\text { laporan ) }\end{array}$ & $\begin{array}{l}\text { Ada } \\
\text { (foto selfi, } \\
\text { mengumpulka } \\
\text { n laporan) }\end{array}$ \\
\hline & $\begin{array}{l}\text { Jum'at, } 02 \\
\text { Oktober } \\
2020\end{array}$ & $\begin{array}{l}\text { Organ } \\
\text { Pencernaa } \\
\mathrm{n}\end{array}$ & $\begin{array}{l}\text { Video } \\
\text { Youtobe } \\
\text { channel ibu } \\
\text { Hanani dan } \\
\text { Sigma Smart } \\
\text { Study }\end{array}$ & $\begin{array}{l}\text { Ada } \\
\text { (foto selfi, } \\
\text { meringkas ) }\end{array}$ & $\begin{array}{l}\text { Ada } \\
\text { (foto selfi, } \\
\text { mengumpulka } \\
\text { n tugas, } \\
\text { bertanya ) }\end{array}$ \\
\hline $\begin{array}{l}\text { BAB V } \\
\text { Zat } \\
\text { Aditif } \\
\text { dan Zat } \\
\text { Adiktif } \\
\end{array}$ & $\begin{array}{l}\text { Senin, } 26 \\
\text { Oktober } \\
2020\end{array}$ & $\begin{array}{l}\text { Zat aditif } \\
\text { dan zat } \\
\text { adiktif }\end{array}$ & $\begin{array}{l}\text { Video } \\
\text { Youtobe } \\
\text { channel ibu } \\
\text { Hanani }\end{array}$ & $\begin{array}{l}\text { Ada } \\
\text { (foto selfi, } \\
\text { meringkas ) }\end{array}$ & $\begin{array}{l}\text { Ada } \\
\text { (foto selfi, } \\
\text { mengumpulka } \\
\text { n tugas, } \\
\text { bertanya ) }\end{array}$ \\
\hline $\begin{array}{l}\text { BAB VI } \\
\text { Sistem } \\
\text { Peredara } \\
\text { n Darah } \\
\text { Manusia }\end{array}$ & $\begin{array}{l}\text { Senin, } 09 \\
\text { November } \\
2020\end{array}$ & $\begin{array}{l}\text { Sistem } \\
\text { Peredaran } \\
\text { Darah } \\
\text { Manusia }\end{array}$ & $\begin{array}{l}\text { Video video } \\
\text { youtobe } \\
\text { channel } \\
\text { Sigma Smart } \\
\text { Study }\end{array}$ & $\begin{array}{l}\text { Ada } \\
\text { (foto selfi, } \\
\text { meringkas, } \\
\text { menggambar) }\end{array}$ & $\begin{array}{l}\text { Ada } \\
\text { (foto selfi, } \\
\text { mengumpulka } \\
\text { n tugas, } \\
\text { bertanya ) }\end{array}$ \\
\hline
\end{tabular}

Berdasarkan grafik 1 dan tabel tersebut di atas menunjukkan bahwa terjadi peningkatan yang signifikan, karena minat dan motivasi belajar siswa sebelum menggunakan video hanya 
21,4\% atau 48 siswa dengan memanfaatkan media yang berbasis video minat dan motivasi peserta didik meningkat menjadi 79,5\% atau 178 siswa, mengalami peningkatan sebesar $58,1 \%$. Berdasarkan minat dan motivasi belajar ternyata terdapat perubahan didalam prestasi belajar. Artinya semakin tinggi motivasi belajar siswa maka nilai rata-rata peserta didik juga semakin tinggi. Hal ini dapat di lihat dari hasil tugas-tugas yang dikerjakan oleh peserta didik. Adapun grafik di bawah ini menggambarkan nilai rata-rata peserta didik dalam mengikuti pembelajaran daring IPA dengan memanfaatkan media pembelajaran berbasis video, dalam setiap bab mulai bab I sampai dengan Bab VI.

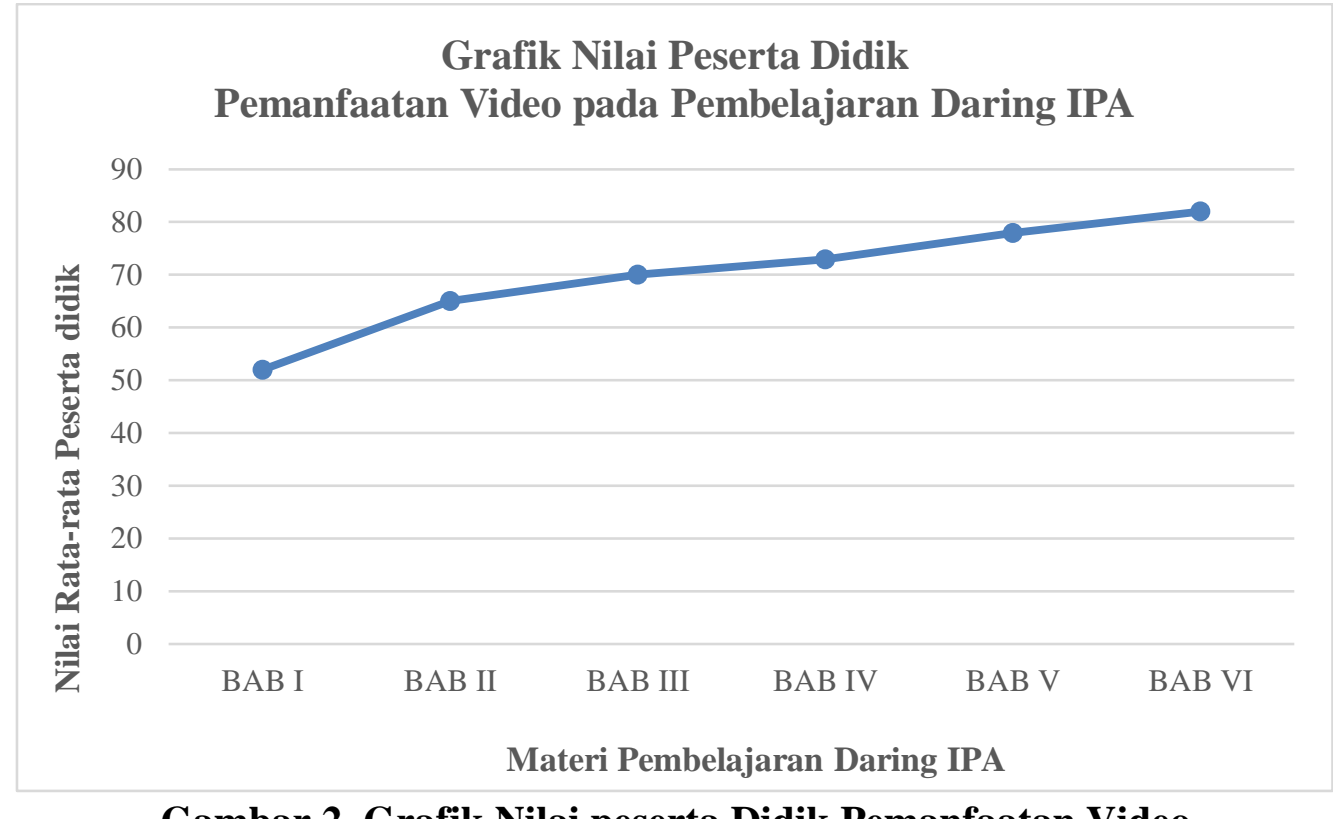

Gambar 2. Grafik Nilai peserta Didik Pemanfaatan Video Pada Pembelajaran Daring IPA

Berdasarkan grafik 2, menunjukkan terjadinya peningkatan nilai rata-rata perserta didik dalam mengikuti pembelajaran daring IPA, ini dapat dilihat pada bab 1 nilai rata-rata peserta yaitu 52 dan terus mengalami peningkatan hingga bab VI mencapai angka 82. Dengan demikian meningkatnya nilai rata-rata peserta didik menunjukkan bahwa minat dan motivasi belajar peserta didik juga meningkat, hal ini disebabkan dengan pemanfaatkan media pembelajaran berbasis video sebagai alternatif dalam pembelajaran daring IPA di MTs. Negeri 1 OKU Timur.

\section{Pembahasan}

Menurut A Cahyadi (2019) bahwa media adalah segala sesuatu yang dapat dipergunakan untuk menyampaikan suatu pesan (massage) dalam proses belajar mengajar sehingga dapat merangsang perhatian dan minat siswa. Menurut A. A Nugroho, R.W.Y (2017) mengatakan bahwa proses belajar mengajar biasanya berlangsung secara tatap muka di dalam kelas dengan dihadiri guru dan siswa. Namun, di masa pandemi covid-19 kegiatan belajar mengajar tidak dapat dilakukan seperti biasanya sehingga mendorong terlaksananya pembelajaran jarak jauh dan atau pembelajaran daring. Diperlukan adanya inovasi dalam rangka memanfaatkan teknologi computer dan jaringan internet dalam pembelajaran IPA agar pembelajaran IPA lebih efektif Pembelajaran daring memerlukan adanya inovasi dan kratifitas dalam rangka memanfaatkan teknologi computer dan jaringan internet dalam pembelajaran IPA agar pembelajaran IPA lebih efektif, menurut W. Saputra (IH. Mu'minah 2021) mengatakan bahwa system pembelajaran yang lebih inofatif, pengajar akan selalu dituntut untuk kreatif, inovatif dalam mencari terobosan pembelajaran, mampu menggabungkan antara teks, gambar, video, animasi gambar atau video dalam satu kesatuan yang saling mendukung guna tercapainya tujuan pembelajaran yang mampu menimbulkan rasa senang selama proses belajar mengajar berlangsung. Menurut A. Niswa (2013) menyatakan variasi penggabungan teks, 
gambar, audio dan animasi gambar dapat berupa video secara tepat sasaran,disajikan melalui presentasi audio visual (gambar dan suara yang dilengkapi dengansuara penuntun berbahasa Indonesia yang jelas dan mudah dipahami dan dikemas dalam program autorun, sehingga CD interaktif siswa saat dan akan sangat menunjang bagi pendalaman materi.

Video sebagai salah satu media dalam pengajaran dan pembelajaran yang dapat membantu para guru mengetahui satu pendekatan baru yang bisa digunakan untuk menarik minat belajar siswa. Dengan demikian, sedikit banyak video merupakan salah satu alternative dalam mengatasi kemerosotan pelajaran dalam pembalajaran daring. Dengan memanfaatkan media pembelajaran berbasi video ini diharapkan dapat mendorong siswa untuk mengerti apa makna tujuan materi dalam belajar, manfaat belajar, serta peningkatan hasil belajar mereka dalam proses belajar mengajar daring.

Pemanfaatan media video pada pembelajaran daring adalah salah satu alternatif agar dapat mencapai hasil yang maksimal dan lebih efektif, menurut Kemp dan Dalton ( Iwan Falahudin, 2014) bahwa manfaat media pembelajaran yang berbasis video yaitu :1) Penyampaian materi pelajaran dapat diseragamkan, 2) Proses pembelajaran menjadi lebih jelas, lengkap dan menarik minat .3)Proses pembelajaran menjadi lebih interaktif, 4)Efisiensi dalam waktu dan tenaga, 5) Meningkatkan kualitas hasil belajar 6) Media memungkinkan proses pembelajaran dapat dilakukan di mana saja dan kapan saja, 7) Media dapat menumbuhkan sikap positif pebelajar terhadap materi dan proses belajar, 8) Mengubah peran pembelajar ke arah yang lebih positif dan produktif, 9)Media dapat membuat materi pelajaran yang abstrak menjadi lebih konkrit, 10) Media juga dapat mengatasi kendala keterbatasan ruang dan waktu, 11)Media dapat membantu mengatasi keterbatasan indera manusia. Videovideo yang dapat dimanfaatkan dalam pembelajaran daring diantaranya : 1) video tutorial, 2) media praktikum berbasis video pada pembelajaran IPA 3) video youtobe dalam pembelajaran IPA.

Pembelajaran IPA pada Madrasah diharapkan dapat menjadi wahana bagi peserta didik untuk mempelajari diri sendiri dan alam sekitar, serta prospek pengembangan lebih lanjut dalam menerapkannya dalam kehidupan sehari-hari. Menurut Galuh Rahayuni ( Dwi Yunita, 2017) mengatakan bahwa Pembelajaran IPA yang sebaiknya dilakukan adalah pembelajaran yang dapat menyiapkan peserta didik untuk melek IPA dan teknologi, mampu berpikir logis, kritis dan kreatif . karena materi-materi yang dipelajari di dalamnya yang bersifat abstrak, dan itu memerlukan pemahaman yang tinggi agar materi-materi yang sifatnya abstrak menjadi kongkret. Pada pembelajaran daring ini guru dituntut untuk kreatif dalam memilih dan menerapkan media pembelajaran yang tepat sesuai dengan materi-materi dalam pelajaran IPA yangsifatnya abstrak menjadi kongkret terlebih dengan materri-materi yang terkait dengan kegiatan praktikum baik kegiatan praktikum Biologi, Fisikan maupun kimia.

Pendidikan yang berkualitas ditunjukkan dari hasil belajar yang diperoleh siswa melalui proses pembelajaran. Pendidikan dikatakan berhasil apabila proses kegiatan belajar mengajar berjalan dengan baik dan sesuai tujuan perencanaan yang dicapai yakni terjadinya perubahan yang positif dalam pengetahuan, pemahaman, nilai dan sikap. Seperti halnya best practice yang telah dilaksanakan penulis di MTs. Negeri 1 OKU Timur bahwa dengan pemanfaatan media pembelajaran yang berbasis video dapat meningkatkan motivasi belajar peserta didik serta dapat meningkatkan prestasi belajar peserta didik.

\section{KESIMPULAN}

Hasil dari seluruh data-data yang diperoleh menunjukkan bahwa dengan memanfaatkan media pembelajaran yang berbasis video sebagai alternatif pada pembelajaran daring IPA dapat meningkatkan minat dan motivasi belajar peserta didik karena sebelum menggunakan video hanya $21,4 \%$ atau 48 siswa dengan memanfaatkan media yang berbasis video minat dan motivasi peserta didik meningkat menjadi $79,5 \%$ atau 178 siswa, mengalami peningkatan sebesar 58,1\%. Berdasarkan motivasi perserta didik terjadi perubahan nilai rata-rata pada peserta didik yaitu pada bab 1 nilai rata-rata peserta yaitu 52 dan terus mengalami peningkatan 
hingga bab VI mencapai angka 82 .

Dengn demikian best practice yang telah dilaksanakan di MTs. Negeri 1 OKU Timur berdampak positf pada seluruh warga madrasah, bagi peserta didik dapat menumbuhkan sikap minat dan motivasi belajar dalam peningkatan prestasi belajar, dan bagi guru sebagai inovasi dan motivasi karena dapat membawa sebuah perubahan yang hasilnya luar biasa.

\section{DAFTAR PUSTAKA}

A.Cahyadi.(2019). Pengembangan Media dan Sumber Belajar: Teori dan Prosedur.

A.Niswa. (2013). Pengembangan Bahan Ajar Mendengarkan Berbasis Video Interaktif Bermediaflash Kelas VIID SMP Negeri 1 Kedamean. Bapala, Vol.1 No.1, 2013

A. A. Nugroho, R. W. Y. Putra, F. G. Putra, and M. Syazali,"Pengembangan blog sebagai media pembelajaran matematika," Al-Jabar J. Pendidik.Mat., vol. 8, no. 2, pp. 197-203, 2017, DOI: https://doi.org/10.24042/ajpm. v8i2.2028

Batubara, Hamdan Husein, dan Delila Sari Batubara.(2015). Penggunaan Video Tutorial Untuk Mendukung Pembelajaran Daring Di Masa Pandemi Virus Corona. Muallimuna: Jurnal Madrasah Ibtidaiyah. Vol 5, No 2 April 2020 Halaman:74-84. http://ojs.uniskabjm.ac.id

Falahudin Iwan (2014) Pemanfaatan Media Pembelajaran : Jurnal Lingkar Widiaswara Edisi 1 No. 4, hal. 114 Hasanah U.(2020) Analisis Efektifitas Pembelajaran On line di Masa Pandemi Covid-19 : Jurnal Pendidikan Guru Sekolah Dasar, hal.33 ummaspul.ejournal.id

Iqbal M, et all. (2019). Pengembangan Video Blog (Vlog) Channel Youtube Dengan Pendekatan STEM Sebagai Media Alternatif Pembelajaran Daring. Jurnal Kelitbangan. Vol. 7 No. 2 hal 135-148

Michels \& Kristin. (2016). Advantages of Live Microscope Video for Laboratory and Teaching Applications. Journal Undergraduate Education. Natural Sciences Education, 45(5), 15.

Mu'minah , L.H.(2021) Pemanfaatan Media Pembelajaran Berbasis Video Sebagai Alternatif DalamPembelajaran Daring IPA Pada Masa Pandemi Covid-19 : Prosiding Penelitia dan Pengabdian 2021, Vol. 1 No. 1 hal.7

Rimba, A. M., Indriwati, S. E \& Suhadi.(2017). Pengembangan Video Penyuluhan Perilaku Hidup Bersih dan Sehat (PHBS) Bermuatan Nilai Karakter terhadap Peningkatan Pengetahuan Masyarakat dalam Menanggulangi Penyakit Diare.Jurnal Pendidikan Teori, Penelitian, dan Pengembangan, 2 (7), 883-888.

Saleh A.M. (2020) Problematik Kebijakan di tengah Pandemi dan Dampaknya terhadap Proses Pembelajaran di Indonesia : OSP Preprints hal. 4. http://osf.10/preprints/pg

Yunita Dwi (2017) Pengaruh Media Video Pembelajaran Terhadap Hasil Belajar IPA Ditinjau dari Keaktifan Siswa. Jurnal Ilmiah Imu Sosial dan Humaniora, vol.3 no.2. DOI: https://doi.org/10.30738/sosio.v3i2.1614 